\title{
Сучасні тенденції поширеності хронічних неінфекційних захворювань серед дорослого населення міста Києва
}

Актуальність проблеми хронічних неінфекційних захворювань (ХНІЗ) зумовлена зростанням їх поширеності та домінуючою роллю у формуванні передчасної смертності та інвалідності населення. Мета роботи - встановити основні тенденції у захворюваності та поширеності ХНІЗ серед дорослого населення м. Києва у 2007-2016 рр. Об'єкт іметоди дослідження. Сучасні тенденції у захворюваності та поширеності ХНІЗ серед населення м. Києва виявлені на підставі аналізу матеріалів форм статистичної звітності (№ 12, № 7, № 35), зведених по м. Києву за 2007-2016 рр. Для аналізу відібрані ті класи ХНІЗ та нозологічні форми, які відіграють провідну роль у формуванні тягаря хвороб через передчасну смертність та інвалідність. Результати. Встановлено, що протягом 20072016 рр. поширеність ХНІЗ серед дорослого населення м. Києва зросла за всіма провідними класами хвороб. Поширеність патологій ендокринної системи зросла за 10 років на 249, 8; системи кровообігу - на 131,2; новоутворень - на 127,2; хвороб кістково-м'язової системи та сполучної тканини - на 59,3, органів травлення на 56, 9 випадки захворювань на 10 тис. дорослого населення. Частота первинної реєстрації захворювань серед дорослого населення м. Києва знизилася за всіма зазначеними класами хвороб. Показано, що повнота охоплення пацієнтів із ХНІЗ диспансерним спостереженням є недостатньою. Так, у м. Києві у 2016 р. диспансерним спостереженням було охоплено лише 38,8\% хворих із патологіями системи кровообігу, у тому числі 60,8\% осіб із гіпертонічною хворобою; 55, 7\% - із ішемічною хворобою серця; 50, 4\% - із цереброваскулярними хворобами. Висновки. Для ефективної реалізації профілактичного напрямку діяльності амбулаторно-поліклінічних закладів м. Києва необхідним є широке запровадження та належне виконання скринінгових програм, цільових профілактичних оглядів, диспансерного спостереження пацієнтів із ХНІЗ. Результати дослідження у подальшому будуть використані для обґрунтування концептуальних напрямів удосконалення амбулаторно-поліклінічної допомоги дорослому населенню м. Києва та розробки оптимізованої моделі консультативно-діагностичного центру.

Ключові слова: хронічні неінфекційні захворювання, поширеність захворювань, доросле населення.

\section{Вступ}

Зниження поширеності хронічних неінфекційних захворювань (XНІ3) - актуальна медико-соціальнапроблема істратегічний напрямок національної політики у сфері охорони здоров'я у більшості країн світу. Пильна увага до проблеми ХНІЗ зумовлена негативними тенденціями у поширеності цих захворювань, а також факторів ризику їх розвитку в усіх європейських країнах і зростанням внеску ХНІЗ у формування загального тягаря хвороб (Грузева Т.С., 2013). В Україні станом на 2012 р., за даними ВООЗ, тягар хвороб становив 21727 років життя, втрачених внаслідок передчасної смертності та інвалідності у розрахунку на 100 тис. населення (World Health Organisation, 2017). У структурі тягаря хвороб перше місце з питомою вагою понад 80,4\% посіли неінфекційні хвороби. Серед окремих класів неінфекційних хвороб провідна роль у формуванні тягаря хвороб належала хворобам системи кровообігу (ХСК) - 40,6\% та злоякісним новоутворенням (3Н) - 11,3\%.

Ключова роль у здійсненні первинної профілактики, своєчасного виявлення, диспансерного спостереження осіб із ХНІЗ належить амбулаторно-поліклінічній ланці системи охорони здоров'я. Моніторинг за поширеністю ХНІЗ є основою планування лікувально-профілактичних заходів, розробки організаційних форм та методів роботи амбулаторно-поліклінічних закладів, а також контролю за ефективністю їхньої діяльності щодо збереження здоров'я населення.

Мета роботи - встановити основні тенденції у захворюваності та поширеності ХНІЗ серед дорослого населення м. Києва у 2007-2016 pp.

\section{Об'єкт і методи дослідження}

Сучасні тенденції у захворюваності та поширеностіХНІЗ серед населення м. Києва виявлені на підставі аналізу матеріалів форм статистичної звітності (№ 12, № 7, № 35), зведених по м. Києву за 2007-2016 рр. Для аналізу були відібрані ті класи хвороб та нозологічні форми, які відіграють найвагомішу роль у формуванні тягаря хвороб через передчасну смертність та інвалідність. Аналіз динаміки захворюваності та поширеності здійснений з використанням показників абсолютного приросту (АП) і темпу приросту (Тпр). Тенденції, властиві динаміці захворюваності та поширеності, виявляли на підставі вирівнювання динамічних рядів за методом найменших квадратів. Статистичний аналіз матеріалів дослідження виконано за допомогою пакета програм «Excel Microsoft».

При інтерпретації даних щодо захворюваності, одержаних на підставі існуючої системи обліку та звітності, враховували, що ці матеріали не відображають «істинної захворюваності» і значною мірою залежать від доступності медичної допомоги та повноти виявлення та реєстрації випадків захворювань.

\section{Результати та їх обговорення}

Встановлено, що ХНІЗ відіграють провідну роль у формуванні смертності, інвалідності та загальної захворюваності населення м. Києва.

\section{Хвороби системи кровообігу}

Найбільшу соціально-медичну проблему серед усіх XНІ3 у м. Києві, як і в Україні та Європейському регіоні в цілому, становлять ХСК. Вони є провідною причиною смерті населення столиці (у 2016 р. питома вага цього класу хвороб у структурі причин смерті досягала 63,9\%), а також інвалідизації дорослого населення столиці (у 2016 р. - 28,4\% у структурі первинної інвалідності).

Щороку у м. Києві серед дорослого населення реєструється 1,7 млн випадків XСК, у тому числі >130 тис. - вперше у житті. Ця патологія посідає перше місце у структурі поширеності хвороб серед дорослого населення м. Києва (з питомою вагою $30,8 \%$ ) і четвертеу структурі первинної захворюваності (з питомою вагою 8,0\%).

У структурі захворюваності дорослого населення м. Києва на ХСК превалюють гіпертонічна хвороба (ГХ) (39,8\%), ішемічна хвороба серця (IXC) (31,4\%) та цереброваскулярні хвороби (ЦВХ) $(14,9 \%)$. У структурі поширеності ХСК іх питома вага становить 53,3; 39,2 та 14,9\% відповідно. 
Таблиця 1. Первинна захворюваність та поширеність ХСК серед дорослого населення м. Києва у 2007-2016 рр.

\begin{tabular}{|c|c|c|c|c|c|c|c|c|c|c|c|c|}
\hline \multirow{2}{*}{$\begin{array}{c}\text { Клас, нозологічна форма } \\
\text { захворювань }\end{array}$} & 2007 & 2008 & 2009 & 2010 & 2011 & 2012 & 2013 & 2014 & 2015 & 2016 & \multicolumn{2}{|c|}{$\begin{array}{c}\text { Динаміка } \\
2016 / 2007\end{array}$} \\
\hline & \multicolumn{10}{|c|}{ Первинна захворюваність на 10 тис. дорослого населення } & AП & Тпр, \% \\
\hline XCK & 648,6 & 641,0 & 601,6 & 601,0 & 602,8 & 593,2 & 578,2 & 596,4 & 566,8 & 574,3 & $-74,3$ & $-11,5$ \\
\hline ГХ (всі форми) & 269,9 & 261,5 & 247,9 & 247,0 & 244,0 & 235,5 & 230,6 & 232,5 & 224,6 & 228,7 & $-41,2$ & $-15,3$ \\
\hline IXC & 186,0 & 176,1 & 167,0 & 164,1 & 158,7 & 152,1 & 153,3 & 165,1 & 164,5 & 180,2 & $-5,8$ & $-3,1$ \\
\hline • в тому числі гострий інфаркт міокарда & 13,2 & 12,9 & 11,0 & 11,4 & 10,7 & 10,3 & 10,4 & 11,2 & 11,4 & 11,6 & $-1,6$ & $-12,1$ \\
\hline • стенокардія & 68,1 & 63,1 & 59,9 & 59,3 & 56,3 & 52,2 & 48,8 & 48,1 & 50,8 & 47,7 & $-20,4$ & $-30,0$ \\
\hline • ЦВХ & 89,7 & 90,4 & 86,8 & 91,8 & 96,5 & 96,4 & 93,8 & 92,2 & 81,8 & 83,0 & $-6,7$ & $-7,5$ \\
\hline • в тому числі інсульт & 26,7 & 27,8 & 25,1 & 23,6 & 21,5 & 20,3 & 19,8 & 21,2 & 22,6 & 21,9 & $-4,8$ & $-18,0$ \\
\hline & & & & иреніст & на 10 ти & доросл & насел & & & & & \\
\hline XCK & 7214,8 & 7320,6 & 7355,8 & 7371,6 & 7332,8 & 7420,6 & 7241,2 & 7383,2 & 7367,5 & 7346,0 & 131,2 & 1,8 \\
\hline ГХ (всі форми) & 3333,9 & 3317,0 & 3329,4 & 3379,7 & 3357,4 & 3395,9 & 3253,8 & 3322,9 & 3335,7 & 3335,2 & 1,3 & 0,0 \\
\hline IXC & 2781,0 & 2767,4 & 2764,2 & 2789,0 & 2779,3 & 2840,1 & 2736,1 & 2796,4 & 2833,0 & 2828,9 & 47,9 & 1,7 \\
\hline Стенокардія & 1141,6 & 1139,2 & 1110,2 & 1103,4 & 1105,8 & 1088,3 & 1007,7 & 996,1 & 1004,2 & 977,8 & $-163,8$ & $-14,3$ \\
\hline ЦВХ & 650,0 & 640,9 & 658,4 & 669,7 & 676,8 & 668,3 & 645,9 & 656,6 & 641,3 & 636,9 & $-13,1$ & $-2,0$ \\
\hline
\end{tabular}

Аналіз динаміки поширеностіХСК серед дорослого населення м. Києва засвідчив, що протягом 2007-2016 рр. цей показник зріс на 131,2 випадку на 10 тис. дорослого населення (з 7214,8 до 7346,0) (табл. 1). Такі динамічні зміни за цим класом хвороб відбулися за рахунок IXC, рівень якої за період спостереження зріс на 47,9 випадку з 2781,0 до 2828,9 на 10 тис. дорослого населення.

Одним із найпоширеніших захворювань у м. Києві, як і в Україні в цілому, є артеріальна гіпертензія (АГ). Крім того, АГ є чинником ризикудля інших ХСК. У осіб із високим артеріальним тиском у 3-4 рази частіше розвивається IXC і в 7 разів частіше - порушення мозкового кровообігу (Коваленко В.М., Корнацький В.М. (ред.), 2015). Тому своєчасне виявлення хворих на АГ та ефективний контроль артеріального тиску - важливі напрямки вторинної профілактики XСК, запобігання передчасній смертності та інвалідизації населення

Завдяки реалізації Національної програми профілактики і лікування артеріальної гіпертензії у м. Києві вдалося підвищити рівень виявлення АГ серед населення. Протягом 2007-2016 рр. поширеність АГ серед дорослого населення м. Києва стабільно становила 33,3\%, що відповідає даним спеціальних епідеміологічних досліджень ДУ «Національний науковий центр «Інститут кардіології імені академіка М.Д. Стражеска» НАМНУкраїни», проведених серед міського населення (Українська асоціація кардіологів, 2008).

Виявлена тенденція до зниження поширеності ЦВХ у столиці (на 2\%, з 650,0 до 636,9 на 10 тис. дорослого населення) може бути позитивним наслідком підвищення контролю над АГ у м. Києві. Аналогічним чином можна пояснити тенденцію до зниження частоти інсультів та стабілізації частоти гострих інфарктів міокарда протягом 2007-2016 рр.

Важливим методом активного спостереження контингенту пацієнтів із ХCК є диспансеризація. Саме від ефективності реалізації диспансерного спостереження залежить частота первинної інвалідизації та летальність серед означеної категорії хворих.

Показник повноти охоплення диспансерним спостереженням хворих на ХСК має наближатися до 100\%. У м. Києві у 2016 р. диспансерним спостереженням було охоплено лише $38,8 \%$ хворих на XCК, у тому числі 60,8\% пацієнтів із ГX, 55, 7\% - із IXC, 50,4\% із ЦВХ. Наведені показники свідчать про наявність істотних недоліків в організації диспансерного спостереження пацієнтів із ХСК та необхідність удосконалення амбулаторно-поліклінічної допомоги для цих хворих.

Аналіз динаміки рівнів первинної захворюваності на ХСК виявив тенденцію до зниження протягом 2007-2016 рр. частоти первинної реєстрації захворювань по класу в цілому, а також щодо усіх нозологічних форм. На нашу думку, цю тенденцію не слід інтерпретувати як наслідок успішної реалізації первинної профілактики ХСК. За останні 10 років знизилася первинна захворюваність за всіма класами хвороб (за винятком хвороб нервової системи), що може бути зумовлено зниженням повноти виявлення та реєстрації захворювань серед населення.

На частоту звернень пацієнтів із приводу захворювань до амбулаторно-поліклінічних закладів суттєво впливає суб'єктивне ставлення хворого до свого стану здоров'я, а також рівень організації та доступності медичної допомоги.

Згідно з результатами спеціально організованого вибіркового соціологічного дослідження, проведеного Київським міжнародним інститутом соціології, 35,6\% опитаних мешканців м. Києва у разі хвороби, яка мала місце протягом останніх 12 міс, не зверталися до лікарів. І тільки 25\% дорослих киян за останній рік відвідали амбулаторно-поліклінічні заклади (Тимошевська В. та співавт., 2016).

За матеріалами вибіркового дослідження доступності медичної допомоги, проведеного Держкомстатом України, у 2015 р. у м. Києві, частка домогосподарств, де будь-хто із членів родини протягом останніх 12 міс за потреби не зміг отримати медичну допомогу, придбати ліки та медичне приладдя, становила 29,3\% (Державна служба статистики України, 2016).

Серед домогосподарств, члени яких потребували, але не отримали медичної допомоги, 42,7\% не змогли відвідати лікаря, 30,5\% - провести медичне обстеження. Занадто висока вартість була названа респондентами домінуючою причиною неможливості відвідати лікаря (79,4\% опитаних) та провести медичне обстеження (95,5\%).

Таким чином, зниження доступності медичної допомоги вагомий чинник, який сьогодні впливає на частоту звернення населення за медичною допомогою і, відповідно, повноту виявлення захворювань, у тому числі ХНІЗ.

\section{Злоякісні новоутворення}

ЗН - важлива медико-соціальна проблема - посідають друге місце у структурі смертності населення м. Києва (з питомою вагою $17,2 \%$ у 2016 р.) та друге місце - у структурі первинної інвалідності дорослого населення (з питомою вагою 27,9\% у 2016 р.).

Кількість хворих на ЗН у 2016 р. становила 82357 осіб; порівняно із 2007 р. інтенсивний показник у розрахунку на 100 тис. населення зріс на 34,2\% (з 2110,7 до 2832,9 випадку). 3 урахуванням менш інтенсивного приросту первинної захворюваності (на 10,0\%) та підвищення індексу накопичення ЗН за цей період ( з 6,3 до 7,7), а також тенденції до зниження смертності від 3Н (з 164,0 до 162,0 на 100 тис. населення), такі зміни можна оцінити позитивно і пояснити подовженням тривалості життя хворих на $3 \mathrm{H}$.

Щороку вперше у житті діагноз ЗН реєструють у >10 тис. киян (у 2016 р. - у 10690 осіб).

Динаміка первинної захворюваності на ЗН впродовж 20072016 рр. характеризувалася вираженою тенденцією до росту: цей показник зріс за 10 років на 10\% (на 33, 5 випадку), з 334,2 до 367,7 на 100 тис. населення (рис. 1).

Структура первинної захворюваності на ЗН мала суттєві відмінності залежно від статі. Провідними локалізаціями 3 Н серед чоловіків у м. Києві були: передміхурова залоза (13,8\%), шкіра (крім меланоми) (11,8\%), трахея, бронхи, легеня (10,3\%), ободова кишка $(8,5 \%)$, шлунок $(7,5 \%)$, пряма кишка $(5,7 \%)$, сечовий міхур (5,3\%) (рис. 2). ЗН наведених локалізацій становили у 2016 р. $>60 \%$ усіх вперше виявлених випадків 3 н у чоловіків.

У жінок перші 5 місць (із загальною питомою вагою 65\%) у структурі захворюваності на ЗН посіли: рак молочної залози $(22,7 \%), 3$ Н тіла, шийки матки і яєчника (18,4\%), ЗН шкіри (крім меланоми) (10,6\%), ободової кишки (7,5\%), щитовидної залози (5,8\%) (рис. 3).

Результати аналізу динаміки частоти первинної реєстрації ЗН різних локалізацій із вирівнюванням динамічних рядів за методом найменших квадратів свідчать, що за останніх 10 років середжителів столиці сформувалася тенденція до зниження первинної захворюваності на рак шлунка, рак легені та до зростання захворюваності на рак молочної залози, шийки матки, тіла матки, шкіри, щитовидної залози, передміхурової залози, ободової кишки. У 2016 р. найвищий абсолютний приріст у кількості випадків на 100 тис. населення порівняно з 2007 р. встановлений для раку молочної залози $(13,9)$, 
Таблиця 2. Первинна захворюваність на ЗН у м. Києві протягом 2007-2016 рр. (на 100 тис. населення)

\begin{tabular}{|c|c|c|c|c|c|c|c|c|c|c|c|c|}
\hline \multirow[t]{2}{*}{ Локалізація 3Н } & \multirow[t]{2}{*}{2007} & \multirow[t]{2}{*}{2008} & \multirow[t]{2}{*}{2009} & \multirow[t]{2}{*}{2010} & \multirow[t]{2}{*}{2011} & \multirow[t]{2}{*}{2012} & \multirow[t]{2}{*}{2013} & \multirow[t]{2}{*}{2014} & \multirow[t]{2}{*}{2015} & \multirow[t]{2}{*}{2016} & \multicolumn{2}{|c|}{$\begin{array}{c}\text { Динаміка } \\
\text { 2016/2007 }\end{array}$} \\
\hline & & & & & & & & & & & Aח & Tnp y \% \\
\hline ЗН усього & 334,2 & 329,0 & 330,6 & 336,4 & 357,3 & 378,3 & 364,7 & 372,4 & 371,8 & 367,7 & 33,5 & 10,0 \\
\hline Ротова порожнина & 6,3 & 4,5 & 6,3 & 6,8 & 6,9 & 8,1 & 6,4 & 8,6 & 8,1 & 8,6 & 2,2 & 34,9 \\
\hline Шлунок & 24,0 & 22,2 & 21,2 & 21,6 & 21,9 & 21,8 & 23,1 & 20,9 & 20,0 & 20,5 & $-3,5$ & $-14,6$ \\
\hline Ободова кишка & 24,7 & 26,3 & 25,3 & 25,1 & 27,5 & 27,8 & 26,8 & 27,7 & 28,5 & 29,1 & 4,4 & 17,8 \\
\hline Пряма кишка & 18,7 & 19,4 & 19,4 & 19,5 & 18,4 & 20,4 & 19,6 & 20,8 & 19,8 & 17,9 & $-0,8$ & $-4,2$ \\
\hline Легеня & 24,7 & 26,3 & 25,2 & 25,6 & 23,8 & 25,1 & 24,8 & 25,2 & 24,8 & 22,8 & $-1,9$ & $-7,7$ \\
\hline Шкіра (всі форми) & 22,8 & 24,1 & 22,3 & 21,4 & 23,9 & 27,8 & 26,6 & 28,9 & 27,9 & 27,8 & 5,0 & 21,8 \\
\hline Молочна залоза & 73,3 & 72,1 & 70,7 & 73,3 & 76,4 & 81,3 & 79,8 & 83,4 & 91,0 & 87,2 & 13,9 & 19,0 \\
\hline Шийка матки & 14,9 & 13,4 & 14,6 & 15,1 & 14,8 & 14,3 & 15,8 & 15,3 & 17,1 & 15,1 & 0,1 & 0,9 \\
\hline Тіло матки & 33,0 & 31,9 & 33,7 & 32,9 & 36,1 & 38,1 & 33,8 & 36,9 & 37,7 & 36,7 & 3,7 & 11,1 \\
\hline Яєчники & 15,4 & 16,0 & 18,0 & 16,9 & 17,9 & 18,2 & 17,3 & 17,9 & 17,4 & 18,1 & 2,6 & 17,1 \\
\hline Передміхурова залоза & 37,3 & 37,0 & 34,8 & 37,5 & 50,9 & 51,1 & 49,7 & 48,8 & 46,6 & 48,6 & 11,3 & 30,4 \\
\hline Щитовидна залоза & 11,9 & 12,6 & 11,4 & 10,9 & 12,7 & 16,4 & 14,0 & 16,9 & 15,3 & 14,7 & 2,8 & 23,5 \\
\hline Лімфатична та кровотворна тканина & 18,9 & 19,1 & 19,5 & 18,8 & 19,2 & 21,1 & 20,8 & 20,8 & 21,4 & 22,4 & 3,4 & 18,1 \\
\hline
\end{tabular}

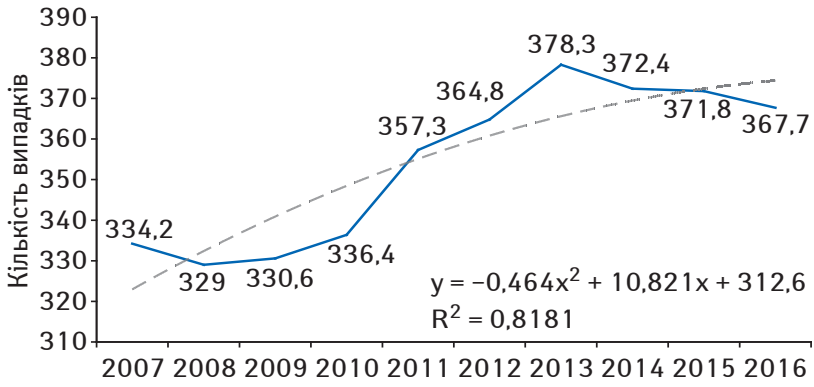

Рис. 1. Динаміка захворюваності населення м. Києва на 3Н у 2007-2016 рр. (на 100 тис. населення)

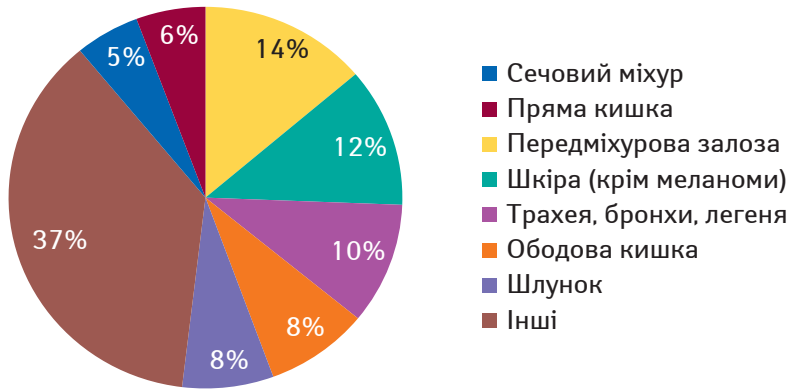

Рис. 2. Розподіл вперше зареєстрованих 3 у у чоловіків за локалізацією, м. Київ, 2016 р.

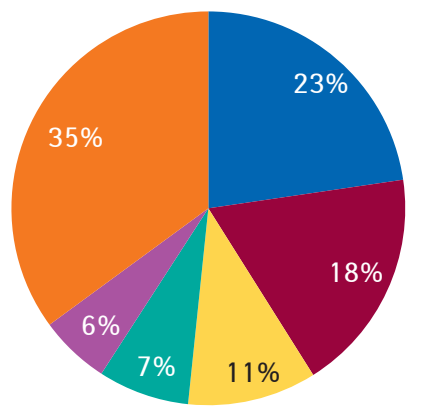

- Молочна залоза

- Тіло, шийка матки, яєчник

Шкіра (крім меланоми)

п Ободова кишка

- Щитовидна залоза

- Інші

Рис. 3. Розподіл вперше зареєстрованих 3Н у жінок за локалізацією, м. Київ, 2016 р.

передміхурової залози (11,3), шкіри з меланомою включно $(5,0)$, ободової кишки $(4,4)$. Найшвидшими темпами за досліджуваний період зростала захворюваність на рак ротової порожнини (на 34,9\% за 10 років), передміхурової залози (30,4\%), щитовидної залози (23,5\%), шкіри з меланомою включно (21,8\%) (табл. 2).

Актуальною для м. Києва проблемою залишається своєчасне виявлення 3Н. У 2016 р. 58,8\% випадків первинної онкопатології виявлено шляхом активних профілактичних оглядів населення із використанням скринінгових обстежень (у 2006 р. - 40,5\%). у 2016 р. найбільша частка ЗН вперше діагностована на профоглядах за такими локалізаціями: шкіра - 99,3\% (меланома $87,4 \%)$, тіло матки - 87,3\%, щитовидна залоза - 86,3\%, сечовий міхур - 81,2\%. Питома вага 3Н, виявлених активно під час профоглядів, суттєво зросла порівняно з 2007 р., коли відповідні показники становили: шкіра - 85,6\% (меланома - 69,6\%), тіло матки - 74,0\%, щитовидна залоза - 60,9\%, сечовий міхур - 25, $1 \%$.

Стабільно невеликою протягом усього періоду спостереження була частка виявлених на профоглядах випадків раку легені (6,7\% у 2007 р.; 6,7\% у 2016 р.). Зазначимо, що саме раку легені притаманний найвищий у 2016 р. показник задавненості - 29,1\% (2007 р. $25,2 \%)$ та дорічної летальності (52,3\%). Така ситуація свідчить про неефективність існуючої системи організації профілактичних флюорографічних обстежень та необхідність її удосконалення.

Питома вага задавнених форм середвперше виявлениху 2016 р. 3Н за всіма локалізаціями становила 9,4\% (у 2007 р. - 12,5\%).

Залишаються високими показники виявлення ЗН узадавнених стадіях у разі їх візуальної локалізації (ротова порожнина - 25,2\%, молочна залоза - 15,5\%, пряма кишка - 12,7\%).

Пізня діагностика ЗН значною мірою зумовлена порушенням системи безоплатних профоглядів населення, системи загальної диспансеризації, низькою ефективністю системи профілактичних заходів, недосконалістю освітніх програм, відсутністю відповідної соціальної реклами (Медведовська Н.В., 2012).

Провідна роль у своєчасному виявленні ЗН належить амбулаторно-поліклінічній ланці охорони здоров'я. Широке запровадження та належне виконання скринінгових програм, цільових онкологічних профоглядів, диспансерного спостереження хворих із передпухлинною патологією - важливі складові реалізації цього напрямку профілактичної діяльності амбулаторно-поліклінічних закладів, а поліпшення їх оснащеності діагностичним обладнанням - необхідна умова для його реалізації.

\section{Хвороби ендокринної системи, розлади харчування, порушення обміну речовин}

Означені патології характеризувалися найшвидшими темпами приросту поширеності серед киян віком >18 років протягом 2007-2016 рр. За 10 років поширеність хвороб цього класу зросла на 32,0\% - з 779,8 до 1029,6 на 10 тис. дорослого населення.

У структурі загальної ендокринної захворюваності переважали цукровий діабет (ЦД) (38,0\%) та патологія щитоподібної залози (36,8\%). Найшвидшими темпами за 10 років зросла поширеність гіпотиреозу (на 80,3\% - з 30,5 до 55,0 на 10 тис. дорослого населення) та тиреоїдиту (на 63,4\% - з 71,9 до 117,5 відповідно). Найбільший абсолютний приріст поширеності (на 70,7 випадку - з 119,9 до 190,6 на 10 тис. дорослого населення) відзначено для нетоксичного вузлового зобу.

Поширеність ЦД зросла за 10 років на 9,7\% (з 356,9 до 391,4 випадку на 10 тис. дорослого населення). Така тенденція спричинена зростанням поширеності ЦД 2-го типу, бо поширеність інсулінозалежного ЦД, навпаки, знизилася за 10 років на 55,2\% (з 49,3 до 22,1 на 10 тис. дорослого населення). Серед загальної кількості дорослих хворих на Цд 5,6\% у 2016 р. становили пацієнти із інсулінозалежним ЦД (у 2006 р. - 13,8\%).

Своєчасне виявлення та якісне диспансерне спостереження хворих на ЦД дозволяє знизити ризик розвитку ускладнень цієї патології. Частка хворих на ЦД, які мають судинні ускладнення різної локалізації, залишається високою - 37,0\% (2006 - 39,6\%). ЦД є проблемою не лише медичною, але й соціальною, ця патологія стає причиною ураження різних органів і систем, що доволі 
часто призводить до інвалідності хворого. у 2016 р. у структурі первинної інвалідності дорослого населення питома вага хвороб ендокринної системи становила 6,0\%, з них 82,2\% припадало на ЦД як причину стійкої втрати працездатності.

Диспансерним спостереженням у 2016 р. було охоплено $88,5 \%$ пацієнтів із ендокринними хворобами, у тому числі 92,3\% хворих на ЦД, 92,1\% - на вузловий зоб, 91,4\% - на гіпотиреоз, 86,4\% - на тиреотоксикоз, 93,0\% - на тиреоїдити.

Первинна захворюваність на хвороби ендокринної системи, розлади харчування, порушення обміну речовин за 10 років знизилася на 16,5\% (з 112,5 до 93,9 на 10 тис. дорослого населення).

Викликає занепокоєння виявлена тенденція до зниження частоти первинної реєстрації ЦД (рис. 4). За 10 років рівень захворюваності на ЦД знизився на 25,3\% (з 35,2 до 26,3 на 10 тис. дорослого населення). Така тенденція не відповідає загальній тенденції, притаманній для Європейського регіону щодо зростання частоти розвитку цього захворювання, і може бути спричинена неповнотою виявлення ЦД (Tamayo T. et al., 2014).

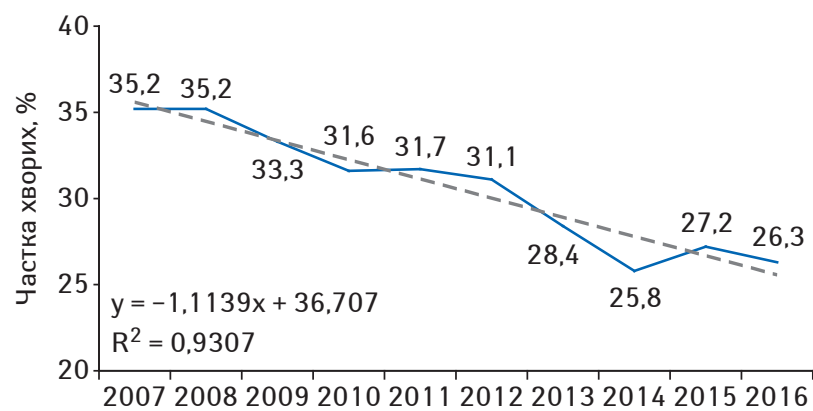

Рис. 4. Динаміка первинної захворюваності на ЦД дорослого населення у м. Києві (на 100 тис. населення)

ЦД 2-го типу становить 95\% усіх вперше діагностованих випадків ЦД серед дорослого населення. Зазначено несвоєчасність виявлення ЦД - кожний п'ятий $(21,7 \%)$ серед вперше виявлених випадків ЦД діагностують на такій стадії захворювання, коли вже розвинулися ускладнення.

Первинна захворюваність на вузловий зоб, тиреоїдит, тиреотоксикоз також за досліджуваний період знизилася. Набутий гіпотиреоз був єдиною серед хвороб ендокринної системи нозологічною формою, захворюваність на яку за 10 років зросла (на 60,5\% - з 4,3 до 6,9 на 10 тис. дорослого населення).

\section{Хвороби органів травлення}

Хвороби органів травлення (ХОТ) стабільно посідають четверте місце у структурі смертності киян (4,4\% у 2016 р.) і третє місце у структурі поширеності хвороб серед дорослого населення м. Києва (12,2\% у 2016 р.). Рівень поширеності ХОТ зріс за 10 років на 2\% - з 2856,8 до 2913,7 випадку на 10 тис. дорослого населення. Серед ХНІЗ у структурі цього класу хвороб найбільшу частку становили холецистит та холангіт $(29,7 \%)$, хвороби підшлункової залози (18,3\%), виразка шлунка та дванадцятипалої кишки (8,5\%)

Найшвидшими темпами впродовж 2007-2016 рр. зростала поширеність хвороб підшлункової залози (на 15,9\% - $з$ 459,8 до 533,0 на 10 тис. дорослого населення).

Диспансерним спостереженням у 2016 р. було охоплено лише половину $(51,9 \%)$ хворих наХОТ, у тому числі 86,9\% осіб із виразкою шлунка та дванадцятипалої кишки, 51,2\% - із холециститом, холангітом, 77,9\% - із цирозом печінки, 69,6\% - із хронічним гепатитом, 50,7\% - із патологією підшлункової залози.

Первинна захворюваність на ХОТ знизилася впродовж 2007 2016 рр. на 32,8\% (з 291,7 до 258,9 випадку на 10 тис. дорослого населення). Ця тенденція сформувалася за рахунок зниження частоти первинного виявлення практично усіх нозологічних форм, які формують зазначений клас хвороб, за винятком патологій підшлункової залози, рівень захворюваності на які залишався практично незмінним.

\section{Хвороби кістково-м'язової та сполучної тканини}

Патології кістково-м'язової та сполучної тканини посідають третє місце у структурі первинної інвалідності дорослого населення і є причиною кожного десятого (10,0\% у 2016 р.) її випадку.

Протягом останніх 10 років серед дорослого населення поширеність хвороб кістково-м'язової системи та сполучної ткани- ни зросла на 4,3\% (з 1376,0 до 1435,3 на 10 тис.). Найбільш швидкими темпами зростала поширеність уражень міжхребцевих дисків (на 51,75\%) та сольової артропатії (на 26,7\%), у тому числі подагричної артропатії (на 82,5\%).

Впродовж періоду спостереження зросла і частота первинної реєстрації сольових артропатій (на $30,8 \%$ ), у тому числі подагричних (на 45,8\%). Для решти нозологічних форм цього класу встановлено зниження первинної захворюваності.

Диспансерним спостереженням у 2016 р. було охоплено $71,3 \%$ пацієнтів із ревматоїдним артритом, 53,6\% - сольовою артропатією, 33,4\% - із ураженням міжхребцевих дисків.

\section{Висновки}

У результаті проведеного дослідження встановлено, що для м. Києва характерний неепідемічний тип патології: у структурі загальної захворюваності, інвалідності, смертності населення провідне значення мають ХНІЗ. Серед них найбільш актуальною проблемою є ХСК та $3 \mathrm{H}$.

Протягом 2007-2016 рр. у м. Києві поширеність ХНІЗ зросла за всіма провідними класами хвороб за рахунок накопичення контингенту хронічних хворих. Рівень поширеності хвороб ендокринної системи виріс за 10 років на 249,8, ХСК - на 131,2, новоутворень - на 127,2, хвороб кістково-м'язової системи та сполучної тканини - на 59,3, ХОТ - на 56,9 випадку захворювань на 10 тис. дорослого населення.

За цей же період рівні первинної захворюваності серед дорослого населення м. Києва знизилися за всіма зазначеними класами хвороб. Ця тенденція свідчить про необхідність удосконалення організації амбулаторно-поліклінічної допомоги киянам, підвищення її доступності та якості для забезпечення повного і своєчасного виявлення ХНІЗ як важливої складової їхньої вторинної профілактики.

Встановлено, що повнота охоплення пацієнтів із XНІЗ диспансерним спостереженням $€$ недостатньою. Так у м. Києві у 2016 р. диспансерним спостереженням було охоплено тільки $38,8 \%$ пацієнтів із ХСК, у тому числі 60,8\% пацієнтів із ГХ; 55,7\% із IXC, 50,4\% - із ЦВX. Це свідчить про наявність істотних недоліків в організації диспансерного спостереження пацієнтів із ХСК та необхідність удосконалення амбулаторно-поліклінічної допомоги для цих хворих.

Таким чином, для ефективної реалізації профілактичного напрямку діяльності амбулаторно-поліклінічних закладів необхідне широке запровадження та належне виконання скринінгових програм, цільових профоглядів, диспансерного спостереження пацієнтів із ХНІЗ.

Результати дослідження у подальшому будуть використані для обґрунтування концептуальних напрямів удосконалення амбулаторно-поліклінічної допомоги дорослому населенню м. Києва та розробки оптимізованої моделі консультативно-діагностичного центру.

\section{Список використаної літератури}

Грузева Т.С. (2013) Борьба с хроническими неинфекционными заболеваниями: европейский и украинский контекст. Здоровье - основа человеческого потенциала: проблемы и пути их решения, 1(8): 291-294.

Державна служба статистики України (2016) Самооцінка населенням стану здоров'я та рівня доступності окремих видів медичної допомоги у 2015 році (ukrstat.org/uk/druk/publicat/kat_u/publdomogosp u.htm).

Коваленко В.М., Корнацький В.М. (ред.) (2015) Стрес і хвороби системи кровообігу. ННЦ "Інститут кардіології імені М.Д. Стражеска» НАМН України, Київ, 352 с

Медведовська Н.В. (2012) Регіональні особливості захворюваності на онкологічну патологію та ї̈̈ профілактика в сучасних умовах. Україна. Здоров'я нації. 4(24): 9-14.

Тимошевська В., Захожа В., Степурко Т. та ін. (2016) Індекс здоров'я. Україна-2016. Результати загальнонаціонального дослідження. Київ, 2016. $165 \mathrm{c}$.

Українська асоціація кардіологів (2008) Рекомендації Української асоціації кардіологів 3 профілактики та лікування артеріальної гіпертензії. Посібник до Національної програми профілактики і лікування артеріальної гіпертензії. Київ, 80 c.

Tamayo T., Rosenbauer J., Wild S.H. et al. (2014) Diabetes in Europe: an update. Diabetes Res. Clin. Pract., 103(2): 206-217.

World Health Organisation (2017) Disease Burden DALYs, 2000-2012 (www. who.int/healthinfo/global_burden_disease/estimates/en/index2.html). 
Современные тенденции

распространенности хронических

неинфекционных заболеваний среди взрослого населения города Киева

\section{В.в. Кравченко}

Резюме. Актуальность проблемы хронических неинфекционных заболеваний (ХНИЗ) обусловлена ростом их распространенности и доминирующей ролью в формировании преждевременной смертности и инвалидности населения. Цель работы - установить основные тенденции в заболеваемости и распространенности ХНИЗ среди взрослого населенияг. Киева в 2007-2016 гг. Объектиметоды исследования. Современные тенденции в заболеваемости и распространенности ХНИЗ среди населения г. Киева выявлены на основании анализа материалов форм статистической отчетности (№ 12, №7, № 35), сведенных по г. Киеву за 2007-2016 гг. Для анализа отобраны классы, играющие ведущую роль в формировании бремени болезней из-за преждевре менной смертности и инвалидности. Результаты. Установлено, что на протяжении 2007-2016 гг. распространенность ХНИЗ среди взрослого населенияг. Киева возросла по всем ведущим классам болезней Распространенность болезней эндокринной системы повысилась за 10 лет на 249,8; системы кровообращения - на 131,2; новообразований - на 127,2; болезней костно-мышечной системы и соединительной ткани - на 59,3; органов пищеварения - на 56,9 случая заболеваний на 10 тыс. взрослого населения. Частота первичной регистрации заболеваний среди взрослого населения г. Киева снизилась по всем перечисленным классам болезней. Показано, что полнота охвата пациентов с ХНИЗ диспансерным наблюдением является недостаточной Так, в г. Киеве в 2016 г. диспансерным наблюдением было охвачено только 38,8\% лиц с патологиями системы кровообращения, в том числе $60,8 \%$ лиц - с гипертонической болезнью; 55,7\% - с ишемической болезнью сердца; 50,4\% - с цереброваскулярными заболеваниями Выводы. Для эффективной реализации профилактического направления деятельности амбулаторно-поликлинических учреждений г. Киева необходимо широкое внедрение и надлежащее выполнение скрининговых программ, целевых профилактических осмотров, диспансерногонаблюдения пациентов СХИЗ. Результаты исследования в дальнейшем будут использованыдля обоснования концептуальныхнаправлений совершенствования амбулаторно-поликлинической помощи взрослому населению г. Киева и разработки оптимизированной модели консультативно-диагностического центра.
Ключевые слова: хронические неинфекционные заболевания, распространенность заболеваний, взрослое население.

\section{Current trends in the prevalence of chronic non-infectious diseases among the adult population of Kyiv \\ V.V. Kravchenko}

Summary. The urgency of the problem of chronic non-infectious diseases is due to the increase in their prevalence and the dominant role in the formation of premature mortalityand disability of the population. Objective-to determine the main trends in the incidence and prevalence of chronic non-epidemic diseases among the adult population of Kyiv in 2007-2016. Materials and methods. Current trends in the incidence and prevalence of chronic non-infectious diseases among the population of Kyiv are revealed on the basis of analysis of materials of forms of statistical reporting in Kyiv for 2007-2016. Results. During 2007-2016, the prevalence of chronic non-epidemic diseases among the adult population of Kyiv has increased in all leading classes of diseases. The prevalence of pathologies of the endocrine system has increased over 10 years by 249.8 , circulatory system by 131.2, tumors by 127.2, disease of the musculoskeletal system and connective tissue by 59.3, digestive organs by 56.9 cases diseases of 10.000 of the adult population. The incidence among the adult population of Kyiv decreased for all of the listed classes of diseases. The completeness of the coverage of patients with chronic non-infectious diseases is insufficient by dispensary observation. In Kyiv in 2016, dispensary observation covered only $38.8 \%$ of patients with cardio-vasculardiseases. Conclusions. To effectively implement the preventive direction in outpatient clinics in Kyiv it is necessary to widely implement and properly perform screening programs, targeted medical examinations, and dispensary observation of patients with chronic non-infectious diseases. The results of the study will be used to determine the conceptual directions for improving outpatient care for the adult population of Kyiv and for the development of an optimized model of a consultative and diagnostic center.

Key words: chronic non-infectious diseases, prevalence, adult population.

\section{Адреса для листування:}

\section{Кравченко Василь Віталійович,}

04112, Київ, вул. Дорогожицька, 9

НМАПО імені П.Л. Шупика,

кафедра управління охороною здоров'я

\section{РЕФЕРАТИВНА ІНФОРМАЦІЯ}

\section{Эффективность двигательных тренировок}

\section{зависит от типа личности}

Согласно данным исследования, представленного на ежегодной конференции Британского психологического общества (British Psychological Society) 11 января 2018 г. в Стратфорде-наЭйвоне (Stratford-upon-Avon), Великобритания, эффективность режима физических тренировок может зависеть от индивидуальных характеристик типа личности. При этом показано, что лица творческого склада более расположены к физическим занятиям на свежем воздухе.

В своем докладе Джон Хэкстон (John Hackston), дипломированный психолог и руководитель научного проекта, отметил, что причиной изучения рассматриваемых закономерностей послужило намерение исследовать, каким образом особенности личности могут послужить ресурсом при планировании физической активности персоналав условиях, когда руководство заинтересовано в развитии и поддержании здоровья своих сотрудников. Так, в ходе исследования установлено, что соответствие индивидуальных характеристик типа личности определенной направленности физических упражнений может повысить как эффективность, так и степень личной удовлетворенности от выполняемой работы.

В процессе реализации поставленной задачи опрошено более 800 человек целого ряда предприятий в несколькихстранах. Приэтом установлено, что люди с экстравертированным типом личностичаще предпочитают тренироваться в спортзале. Люди, склонные к объективно-логическому характеру восприятия действительности, также с большей вероятностью придерживались регламентированного плана физической активности, чем те, которые считали чувственный опыт и ценности более значимыми. Втоже время наиболее творчески настроенным сотрудникам, особенно предпочитающим поиск и работу с новыми идеями, гораздо лучше подходили такие виды активного отдыха, как велоспорт и бег, по сравнению с жестко структурированным спортивным режимом.

В заключение своего доклада Дж. Хэкстон добавил, что наиболее значимый вывод проведенного исследования состоит в том, что в действительности все же не существует типа физических упражнений, которые бычетко отражали тонкие нюансы нашей индивидуальности. С другой стороны, психологическое давление и активная социальная пропаганда здорового способа жизни в сочетании с желанием следовать за толпой и увлеченно выбирать все новые и новые виды и программы физических тренировок, направленных на поддержание физической формы, в поисках личной удовлетворенности жизнью, вероятнее всего, не смогут стать основой долговременной мотивации. Сэтихпозиций гораздо более эффективным мог бы стать индивидуальный план физической активности в соответствии с личными предпочтениями того или иного человека.

В целом, Дж. Хэкстон подчеркнул, что результаты настоящего исследования все же могут быть использованы руководством организаций как практические рекомендации в разработке серии программ по поддержанию физического здоровья персонала, что потенциально может снизить заболеваемость сотрудников, а также повысить степень личной удовлетворенности качеством жизни.

British Psychological Society (2018) Don't like going to the gym? It could be your personality. ScienceDaily, Jan. 10 (https://www.sciencedaily.com/releases/2018/01/180110223412.htm) 